\title{
MILK-BORNE INFECTIONS IN GREAT BRITAIN
}

\author{
BY \\ SIR WILLIAM SAVAGE
}

As long ago as 1857 Dr. Taylor of Penrith showed that an outbreak of typhoid fever was spread by milk. Since that date the literature has been strewn with reports on milk-spread outbreaks of infectious disease, but even so numerous outbreaks remain unrecorded.

The importance of milk as a vehicle for the transmission of disease is due to three factors. The cow may suffer from infections which are common also to man; milk is a suitable medium for the multiplication of most pathogenic organisms and ingestion is an important factor in infection; milk is much handled between cow and consumer, so facilitating its infection.

There are three sources of human milk-spread infections. (1) Bovine infection of the cow may cause tuberculosis, brucellosis, some salmonella infections, and, very rarely, foot and mouth disease and anthrax. (2) Through the cow, but in the animal due to human bacterial strains implanted from human sources, some scarlet fever and other streptococcal infections and certain staphylococcal infections are so disseminated. (3) Specific contamination of the milk after it leaves the cow may be the cause of the enteric infections, i.e. typhoid fever, paratyphoid fever and dysentery, diphtheria, some scarlet fever and other streptococcal infections, most staphylococcal infections, and some salmonella outbreaks.

Although it is possible to estimate with considerable accuracy the extent to which tuberculosis in man is of bovine origin and to make an estimate of human brucellosis, we are without reliable statistics of the extent of other infections.

The Ministry of Health list of milk-borne outbreaks of infection reported in Great Britain between 1900 and 1933 and tabulated by the Committee on Cattle Diseases includes 97 outbreaks, analysed as enteric fever 30 , paratyphoid fever 7 , typhoid and dysentery 4 , diphtheria 14 , scarlet fever 28 , sore throat 5, gastro-enteritis 3, salmonella 3, sickness and diarrhoea 3. G. S. Wilson in The Pasteurization of Milk mentions 69 outbreaks in the years 1912-37 comprising scarlet fe a and septic sore throat 40 , diphtheria 20, the ı...e en rilc diseases 39 , gastroenteritis 14 ; - total 113 . Both authorities stress the marked incompleteness of the records. The comparative prevalence today of these infections can be judged from the following list of 25 outbreaks over the last seven years collected by the author without any detailed study of the literature. They are (excluding tuberculosis) undulant fever 2, scarlet fever 2, diphtheria 1, typhoid fever 2, paratyphoid fever 4, dysentery 11 (Sonne type 9, other types 2 ), salmonella Dublin 2, staphylococcus food poisoning 1. Many outbreaks are never recorded in the literature or only obtain brief mention in not readily accessible annual reports of medical officers of health. It is probably a decided understatement to write that well over 50 per cent. of definite outbreaks are never recorded in available literature.

\section{TUBERCULOSIS}

This in man is the most important disease derived from the cow. Its incidence in human beings depends upon its prevalence in bovines, and the problem of its control is associated with the distribution of tuberculosis in bovines and particularly in cows.

No complete figures are available of the extent of bovine tuberculosis in Great Britain, but three sources of information have been utilized. One, that of animals killed under the Tuberculosis Order, 1913 , is very unreliable and much affected by the extent to which the Order is enforced. It merely supplies corroborative evidence. The results of abattoir findings as to the number of animals found tuberculous on slaughter are a valuable guide, but are somewhat selective, as those slaughtered include an undue percentage of older animals and also many of poor quality.

The only reliable index of the extent of bovine tuberculosis is from the results of systematic testing of cows and cattle with tuberculin. This does supply accurate figures as to the number of infected animals, but this method neither measures the extent of the infection nor the degree of infectivity to man. Unfortunately such findings are only available for selected herds, mainly in connexion with the attested herds scheme or for the formation of tuberculin tested herds. This involves a considerable selection of herds, since those anticipated to 
have a low incidence of tuberculosis are more liable to be selected. Again, the figures are usually given for cattle and not for dairy cows, the essential item from the human standpoint. These limitations must be borne in mind in assessing the results, but the findings are of great value. Ritchie and Stamp (1948) report that up to the end of October, 1947, 29,552 herds comprising $1,171,822$ cattle have qualified for the attested herds register. This represents 13.4 per cent. of the cattle in Great Britain, i.e. in Scotland 30.1 per cent., Wales 24.5 per cent., England 7.9 per cent. When the results are distributed into counties they show very wide variations in incidence. Francis (1947) in his valuable book, Bovine Tuberculosis, gives the figures for each county for cattle (not cows) using the survey figures for 1938. For English counties those with percentages under 10 include Cumberland $(7 \cdot 0)$, Devon $(5 \cdot 6)$, Durham $(4 \cdot 5)$, Yorkshire $(7 \cdot 2-9 \cdot 3)$, Hereford $(5 \cdot 1)$; over 30 per cent. positive were found in Cheshire $(41 \cdot 6)$, Derbyshire $(32 \cdot 2)$, Kent $(37 \cdot 0)$, and Nottinghamshire $(31 \cdot 2)$. Welsh counties ranged from 1.8 to 49.6 per cent. and Scottish counties from $2 \cdot 6$ to $66 \cdot 3$. These figures give the percentages for England as $14 \cdot 1$, for Wales $4 \cdot 1$, and for Scotland 13.0.

Abattoir figures are, in general, in accord with these findings. The Veterinary Record (1948) in an unsigned article gives an interesting series of maps showing the relative incidence in each county based upon this survey and other data.

Ritchie (1948) has made a more recent (1945) estimate and considers the incidence of " reactors," i.e. those positive to tuberculin tests, in cattle in England to be about 20 per cent., with 17-18 per cent. for Great Britain. He considers that this represents 30 to 35 per cent. of infection among cows.

These figures show that the incidence of tuberculosis in cows in Great Britain is very high and varies markedly from county to county. Also it may vary widely within the one county. For example Wilson (1937) in Herefordshire found percentages of 5 to 60 in different districts. The considerable number of herds freed from tuberculosis naturally reduces the percentage of "reactors" but as yet the proportion to the total cow population is too small to affect materially the overall figure. Allowing for the selective nature of these testings, it can be stated reliably that today about 35 per cent. of dairy cows are affected with tuberculosis-in Great Britain. This is a reduction on the figure of $\mathbf{4 0}$ per cent. widely accepted for conditions existing a decade or so ago and is caused by the material progress being made in eradication.
All reactor cows are potential spreaders of tuberculosis to other animals, but their liability to be excretors of tubercle bacilli into the milk essentially depends upon the organs affected witho tuberculosis. Tuberculosis of the udder is undoub $=0$ tedly responsible for the heaviest infection of milko with tubercle bacilli. Savage in 1929 discussed thes incidence and concluded that most of the figures $\frac{\Omega}{2}$ advanced were too high, and estimated clinicallyo detectable udder tuberculosis as 0.2 to 0.3 per cent.? in unselected herds with a figure probably twice as 0 high if all lesions demonstrable by pathologica $\angle$ examination were included. The figures of Torrances (1936-37) support this estimate, as out of a cow. population of 24,500 the use of biological tests? clinical examination, and pathological post-mortem $\omega$ examinations yielded 0.59 per cent. of udder $_{+}$ tuberculosis. With 35 per cent. of reactors this ${ }^{\mathrm{r}}$ figure suggests that 1.7 per cent. of all reactorssuffer from tuberculosis of the udder and are especially liable to spread infection to man. Tubercles bacilli may get into the milk from tuberculous cows without udder lesions, as Griffith and Griffith (1911)e demonstrated to the Royal Commission on Tubercu-e losis, but this is rare; also tubercle bacilli are excreted in dung, particularly from cows with intestinal tuberculosis, and so may get into the milk supply. Stamp (1943) gives a good account of then pathological lesions in udder tuberculosis ando evidence of tubercular foci not visible to the naked eye.

The varied incidence of tuberculosis in dairy cattles in different parts of the country is reflected in a wide range of findings of tubercle bacilli in milk. Per centages ranging from 3 to 15 or even higher ares recorded. When bulked milk is examined the percentage is very high, usually 80 to 100 . For example, in Somerset milk samples collected from undesignated individual herds show over a periofs of 15 years ending in 1948 a percentage positive always between 2.0 and 3.0 , except for 1940 andP 1941 when they were $4 \cdot 4$. and $4 \cdot 3$.

One of the most comprehensive investigations. was undertaken in Scotland (1933). The positives incidence in raw milk in churns for the four main cities was roughly 10 per cent., with Glasgown highest (13.4 per cent.) and Dundee lowest (6.6 per cent.). The incidence of infection increased with the volume of milk from which the sample was: collected. Untreated retailed milk in the sames four towns was 11.76 per cent. positive. Raw milk transported in tanks was $37 \cdot 5$ per cent. positive.

The proportion of human tuberculosis of bovine origin was largely guess work until bacteriologist were able to differentiate the type of tubercle bacillus 
TABLE I

Analysis of Deaths due to Bovine Tuberculosis in the year 1931

\begin{tabular}{|c|c|c|c|c|c|c|c|}
\hline $\begin{array}{c}\text { Type of } \\
\text { Tuberculosis }\end{array}$ & $\begin{array}{l}\text { Deaths } \\
\text { under } \\
5 \text { years }\end{array}$ & $\begin{array}{c}\text { Percentage } \\
\text { Bovine }\end{array}$ & $\begin{array}{c}\text { Calculated } \\
\text { Deaths } \\
\text { of Bovine } \\
\text { Origin }\end{array}$ & $\begin{array}{l}\text { Deaths } \\
\text { over } \\
5 \text { years }\end{array}$ & $\begin{array}{l}\text { Percentage } \\
\text { Bovine }\end{array}$ & $\begin{array}{c}\text { Calculated } \\
\text { Deaths } \\
\text { of Bovine } \\
\text { Origin }\end{array}$ & $\begin{array}{l}\text { All Ages: } \\
\text { Calculated } \\
\text { Bovine } \\
\text { Deaths }\end{array}$ \\
\hline $\begin{array}{l}\text { Respiratory } \\
\text { Nervous ... } \\
\text { Abdominal } \\
\text { Generalized } \\
\text { Other varieties }\end{array}$ & $\begin{array}{r}303 \\
1,286 \\
291 \\
327 \\
55\end{array}$ & $\begin{array}{r}0 \\
34 \\
80 \\
25 \\
20\end{array}$ & $\begin{array}{r}0 \\
437 \\
235 \\
82 \\
11\end{array}$ & $\begin{array}{r}27,355 \\
1,312 \\
235 \\
971 \\
1,115\end{array}$ & $\begin{array}{r}1 \\
20 \\
33 \\
9 \\
5\end{array}$ & $\begin{array}{r}294 \\
262 \\
267 \\
87 \\
56\end{array}$ & $\begin{array}{r}294 \\
699 \\
502 \\
169 \\
67\end{array}$ \\
\hline All kinds & 2,262 & 33 & 765 & 33,553 & $2 \cdot 9$ & 966 & 1,731 \\
\hline
\end{tabular}

present in individual human cases. When a sufficient number of examinations of suitable material was available it was possible to determine with considerable accuracy the proportion of human tuberculosis due to the bovine tubercle bacillus. Savage (1929), using the official statistics of deaths from each variety of tuberculosis first made this calculation in 1927. A special tuberculosis committee of the People's League of Health reinvestigated the problem in 1931 and produced very similar figures. Savage brought his figures up to date in his Mitchell Lecture (1933) and Table $I$ is taken from that lecture.

This and similar estimates have been accepted by all authorities but it is important to consider how far they are reasonably accurate for 1948 . On the one hand tuberculosis as a whole has shown a steady decline, apart from a temporary war increase. We do not know whether that small proportion due to the bovine bacillus has declined proportionately, but in view of the great increase in the heat-treatment of milk in our large towns a considerable decline is likely to have resulted. On the other hand, in Table I there is one considerable miscalculation brought out by recent investigations. Over recent years much evidence has been adduced that the percentage of bovine infections in respiratory tuberculosis is much higher than was originally accepted. This is particularly the case in Scotland where Munro (1939) found 50 cases of bovine infections out of 1,061 respiratory tuberculosis cases, a percentage of $4 \cdot 7$, at Olenlomond Sanatorium, and quotes Griffith's findings at two other Scottish sanatoria of 24 bovine out of 534 cases, a percentage of $4 \cdot 5$. Cutbill and Lynn (1944) in Cheshire found 48 bovine infections in 2,101 pulmonary tuberculosis cases, collected over a period of 15 years, a percentage of $2 \cdot 3$.

In their most recent paper Griffith and Munro (1944) have summarized the figures up to 1944 including their own work and that of Cumming, Lynn and Cutbill, Paget, and others. These are set out briefly in Table II.

The respiratory tuberculosis cases of bovine origin were distributed unequally in the different regions and, in general, with gradually decreasing frequency from the north of Scotland to the south of England.

Lange (1932) of Berlin took the view that most of these pulmonary cases associated with the bovine strain were attributable to infection in connexion with their employment. Undoubtedly some of the infections occur in this way as direct infections from tuberculous cattle, but Griffith and Munro found that for the great majority of the cases the alimentary canal was the portal of entry with infected milk as the probable source of infection. A very few cases were due to infection from a human case infected with the bovine tubercle bacillus.

Human pulmonary tuberculosis due to the bovine bacillus is met with in other countries. For example Knudsen (1947) in Denmark, out of 113 cases isolated 13 (11.5 per cent.) of bovine type, and Ruys in the Netherlands obtained high figures (see Table V).

For calculation purposes it is safe to assume that at least 2 per cent. of cases of respiratory tuberculosis are due to the bovine bacillus. This would add 294 deaths to Table I, increasing the total estimated

TABLE II

INCIDENCE OF BOVINE TUBERCULOSIS

\begin{tabular}{c|c|c|c}
\hline Country & $\begin{array}{c}\text { No. of Cases } \\
\text { Investigated }\end{array}$ & $\begin{array}{c}\text { Cases due to } \\
\text { Bovine } \\
\text { Bacillus }\end{array}$ & $\begin{array}{c}\text { Percentage } \\
\text { Bovine }\end{array}$ \\
\hline $\begin{array}{l}\text { Scotland } \\
\text { England, } \\
\text { Wales } \\
\text { Eire }\end{array}$ & 2,769 & 160 & $5 \cdot 7$ \\
\hline
\end{tabular}


deaths to 2,025. Allowing for the undoubted decline in incidence, about 1,500 deaths a year would be a reasonable estimate for the present time. To these must be added the several thousand cases a year due to bovine infections not resulting in death.

The higher incidence of tuberculosis, in all its forms, of bovine origin in Scotland is well known, but recent work has shown a definite relationship in incidence between town and country. A few examples may be quoted.

Lethem (1946), selecting abdominal tuberculosis in children under five years as usually due to the bovine strain, gives the following figures (Table III).

\section{TABLE III}

COMPARISON OF INCIDENCE BETWEEN TOWN AND COUNTRY

\begin{tabular}{c|r|r|r|r}
\hline \multirow{2}{*}{ Area } & \multicolumn{2}{|c|}{ Death } & Rate per Million \\
\cline { 2 - 5 } & 1921 & 1930 & 1938 & 1944 \\
\hline London: Administrative & & & & \\
County . & 136 & 24 & 12 & 6 \\
Combined county boroughs & 437 & 157 & 63 & 35 \\
Combined urban districts & 366 & 134 & 77 & 42 \\
Combined rural districts .. & 252 & 92 & 63 & 60 \\
& & & & \\
\hline
\end{tabular}

This table illustrates the much higher rates in rural districts, as well as the striking reductions since 1921. By 1930 the proportion of heat-treated milk in the Administrative County of London had risen to about 90 per cent., whereas in 1939 it was 98 per cent., the corresponding figures in county boroughs being 35 per cent. and 60 per cent.

Blacklock (1947), as the result of detailed bacteriological and pathological examinations of children under 13 years infected with the tubercle bacillus, found the bovine percentages to be: primary lung lesions $3 \cdot 6$, abdominal $80 \cdot 8(1914-32)$ and $64 \cdot 7$ (1943-44), cervical glands $70 \cdot 2(1914-35)$ and $67 \cdot 5 \cdot(1943-44)$.
The distribution figures are interesting.

TABLE IV

Distribution

\begin{tabular}{|c|c|c|c|}
\hline Area & $\begin{array}{c}\text { Tuberculous } \\
\text { Meningitis } \\
\text { (\% Bovine) }\end{array}$ & \begin{tabular}{|l} 
Surgical \\
Tuberculosis \\
(\% Bovine)
\end{tabular} & $\begin{array}{l}\text { Heat-treat- } \\
\text { ment of } \\
\text { Milk Supply }\end{array}$ \\
\hline Glasgow & $2 \cdot 3$ & $8 \cdot 8$ & $95 \%$ heat- \\
\hline $\begin{array}{l}\text { Large bor- } \\
\text { oughs in the } \\
\text { Clyde Valley }\end{array}$ & $8 \cdot 2$ & $13 \cdot 6$ & $\begin{array}{l}\text { Consider- } \\
\text { able but } \\
\text { much les } \\
\text { than in } \\
\text { Glasgow }\end{array}$ \\
\hline $\begin{array}{l}\text { Rural areas in } \\
\text { the western } \\
\text { counties }\end{array}$ & $10 \cdot 9$ & $44 \cdot 4$ & $\begin{array}{l}\text { Practically } \\
\text { no heat- } \\
\text { treatment }\end{array}$ \\
\hline
\end{tabular}

Cervical adenitis cases of bovine origin were $\vec{\square}$ $77 \cdot 2$ per cent. bovine in country areas compared으․ with 46.8 per cent. in urban areas.

Price (1938) in Canada examined a series of $500 \overrightarrow{0}$ tuberculous children under 14 years of age over. a period of 13 years. Of these, 9 per cent. of cases of extra-pulmonary tuberculosis were of bovines origin. None of the cases derived from Toronto, $a \frac{\bar{O}}{0}$ large city with 100 per cent. pasteurization of milk:ڤై All the cases of bovine infection came from Ontario $\$$ outside Toronto, and the history invariably revealed $\Rightarrow$ that the child had been fed with raw milk. From 200 samples of raw milk coming into the city to bes pasteurized, 26 per cent. yielded living tubercles. bacilli.

Ruys (1939), including her own findings and those from other Dutch investigators, gives the following figures for 1933-38.

Here the difference between town and country is present but not marked, for it was only since 1940 that pasteurization was extensively used in Amstero dam and elsewhere. For 1933-39 the bovine

TABLE $\mathrm{V}$

INCIDENCE OF BOVINE TUBERCULOSIS IN THE NetherLANDS (1933-38)

\begin{tabular}{|c|c|c|c|c|c|c|c|c|}
\hline & \multicolumn{4}{|c|}{ Pulmonary Tuberculosis } & \multicolumn{4}{|c|}{ All Other Forms of Tuberculosis } \\
\hline & \multicolumn{2}{|c|}{ All Ages } & \multicolumn{2}{|c|}{$0-15$ years } & \multicolumn{2}{|c|}{ All Ages } & \multicolumn{2}{|c|}{$0-15$ years } \\
\hline & $\begin{array}{c}\text { No. Exam- } \\
\text { ined }\end{array}$ & $\begin{array}{c}\text { Bovine } \\
(\%)\end{array}$ & $\begin{array}{c}\text { No. Exam- } \\
\text { ined }\end{array}$ & $\begin{array}{c}\text { Bovine } \\
(\%)\end{array}$ & $\left|\begin{array}{c}\text { No. Exam- Exam } \\
\text { ined }\end{array}\right|$ & $\begin{array}{c}\text { Bovine } \\
(\%)\end{array}$ & $\begin{array}{c}\text { No. Exam- } \\
\text { ined }\end{array}$ & $\begin{array}{c}\text { Bovine } \\
(\%)\end{array}$ \\
\hline $\begin{array}{l}\text { Towns over } 100,000 \\
\text { Rest of the country }\end{array}$ & $\begin{array}{l}699 \\
619\end{array}$ & $\begin{array}{l}4 \cdot 3 \\
6 \cdot 8\end{array}$ & $\begin{array}{l}282 \\
116\end{array}$ & $\begin{array}{l}9 \cdot 2 \\
9 \cdot 4\end{array}$ & $\begin{array}{l}229 \\
260\end{array}$ & $\begin{array}{l}20 \cdot 5 \\
25 \cdot 4\end{array}$ & $\begin{array}{l}71 \\
41\end{array}$ & $\begin{array}{l}21 \cdot 1 \\
43 \cdot 9\end{array}$ \\
\hline
\end{tabular}


percentage for pulmonary tuberculosis in Amsterdam was $9 \cdot 6$, for $1940-44$ only $1 \cdot 8$, with a corresponding decline for other types.

Greater London, Scotland, Canada, the Netherlands, all yield the same picture of a striking reduction of bovine infection with the increased ratio of pasteurized to unpasteurized milk.

Tuberculosis of bovine origin is becoming mainly a rural and small urban district problem.

\section{Brucellosis in Man (Undulant Fever)}

Of the three brucella types $B r$. melitensis, $B r$. abortus and $B r$. suis, the only one which affects dairy cattle in Great Britain is the abortus strain, and this is the cause of contagious abortion in cows and of undulant fever in man. Human infections in Great Britain with the other two strains are rare indeed. They occasionally occur in cows, and Duke (1940) in a bulk sample from an accredited herd of 76 cows isolated $\mathrm{Br}$. melitensis and subsequently from three of the cows. No goats were kept on the farm. Br. suis seems to be rather more prevalent in the U.S.A. Jordan, Borts et al. (1943) describe an outbreak of human brucellosis of 77 cases in Marcus (Iowa) due to Br. suis and mention an earlier outbreak in 1933 due to the same type. In Iowa, a cattle and hog raising state, the official notification rate of human brucellosis over a 12-year period was $6 \cdot 25$ per 100,000 .

Contagious abortion is widely prevalent in Great Britain and its extent can be judged from examinations of milk. These show that some 20 to 30 per cent. of herd milk samples contain living Br. abortus organisms but the percentage varies widely in different districts as shown by the following examples. Pullinger (1934) found 37 per cent. of mixed milk from single farms positive in Cheshire and only 19 per cent. positive in Somerset. Priestley (1934) using positive agglutination reactions as criteria records variable figures, but not less than 20 per cent. of cows showed antibodies specific to $\mathrm{Br}$. abortus in their blood. Smith (1934), in the Aberdeen area, examined samples of milk from 183 single cows and $17(9 \cdot 2$ per cent.) yielded $B r$. abortus. Menton (1940) examined over 1,000 milk samples from the Midlands and $34 \cdot 5$ per cent. showed positive agglutinins, but living $\mathrm{Br}$. abortus was only isolated from $29 \cdot 1$ per cent., whereas a further $9 \cdot 1$ per cent. of samples contained $B r$. abortus but were devoid of agglutinins. Jones (1943) examined 314 samples of milk in the Liverpool area (1933-34) and $15 \cdot 3$ per cent. contained $B r$. abortus, whereas of 408 samples from Kent $14 \cdot 5$ per cent. were positive.

The number of cases each year of undulant fever is not known, as many cases are not diagnosed while the disease is not a notifiable one, but it is possible to give an estimate. The most reliable basis is from large-scale serum agglutination testings. These have not been carried out systematically, particularly in rural areas where a higher incidence may be anticipated. Of 3,175 sera examined from various sources 101 were positive, a percentage of $3 \cdot 18$, which corresponds to 440 new cases a year (Topley and Wilson, 1946). In addition there are many cases of latent infection, with positive serum agglutination below the significant figure of $1 \cdot 80+$, infections associated with the comparatively low pathogenicity of $\mathrm{Br}$. abortus to man. Wilson's (1932) estimate of about 500 new cases a year is probably near the mark.

Dalrymple-Champneys (1948) has collected records of some 900 cases of undulant fever and his paper gives a good account of its epidemiology. The case mortality in his series was only $2 \cdot 3$ per cent., but the disease often causes prolonged incapacity. The majority of recorded cases are single infections but a number of small outbreaks have been recorded in schools, such as those described by Elkington et al. (1940), by Cruickshank and Stevenson (1942), and the small outbreak of four cases at a school at North Molton (1942).

The discrepancy between the high incidence of contagious abortion in cows and the comparatively few cases of undulant fever in man is partly accounted for by the probability of numerous minimal infections ' with no definite symptoms but causing immunity, and partly to the low virulence of $\mathrm{Br}$. abortus to man.

Although human infection is usually due to the consumption of infected raw milk an unknown proportion is spread by direct contact with infected animals amongst farm workers, veterinary surgeons, and men engaged in animal slaughtering. Smith (1934) examined the sera of 106 men associated with meat and slaughtering. He found $16 \cdot 1$ per cent. of sera from slaughtermen and 10.5 per cent. of sera from men working in allied trades agglutinated $B r$. abortus 1:25 or more, compared with 6.8 per cent. from unselected cases. There was no incidence of undulant fever but some evidence of latent infections. This is in accord with other studies, but some investigators consider a material proportion of cases are contact infections.

\section{STREPTOCOCCAL INFECTIONS}

These outbreaks fall into two of the three groups mentioned at the beginning of this paper, namely that due to infection of the milk from human strains implanted in the udder of the cow or to specific 
contamination of the milk after it leaves the cow. The human diseases are outbreaks of septic sore throat, scarlet fever and, very rarely, streptococcal food poisoning.

Mastitis is a prevalent disease in cows, but the organism mainly responsible is Str. agalactiae and this type is harmless to man, as Savage (1911) demonstrated in 1906-11. He further showed that when a cow with mastitis is responsible for a human outbreak of sore throat it is because the udder has been invaded and infected with a Str. pyogenes strain of human origin. This view is now fully accepted and, using the typing methods of Lancefield and Griffith, it can be regularly demonstrated.

The bovine types, including Str. agalactiae, may or may not be haemolytic but are nearly all Type B. Isaac and Nussbaum (1940), for example, examined 93 milk samples for haemolytic streptococci: Type A strains were absent and Type B were over 80 per cent. The pathogenic strains are about 90 per cent. Type $A$ and this type includes all those responsible for sore throat outbreaks. They belong, however, to a number of Griffith types.

These pathogenic streptococci do not readily establish themselves in the bovine udder, but this is facilitated if there are udder or teat lesions. This accounts for the comparative rarity of such outbreaks in Great Britain, although they seem to be more prevalent in the U.S.A. Examples of widespread outbreaks are the Colchester outbreak in 1905 with over 600 cases and the Hove-Brighton outbreak of 1929-30 with more than 1,000 cases and over 60 deaths.

Until the last 30 years or so, milk-spread outbreaks of scarlet fever were ascribed to direct infection of the milk from a case or carrier. Although this is the method of spread in some instances, the evidence strongly suggests that the majority are due to udder infection with the pathogenic streptococcus, exactly as for sore throat outbreaks. The evidence is along four lines.

Various investigators have shown that Str. pyogenes strains grow with difficulty and slowly in ordinary milk. Jones demonstrated this as early as 1928 and ascribed it to a definite inhibitory substance in milk, destroyed when milk is boiled. Davis (1914) showed the same finding for milk at $26^{\circ} \mathrm{C}$. using a strain directly isolated from a sore throat outbreak at Chicago and confirmed that with sterile milk considerable multiplication occurred. Pullinger and Kemp (1937) found similar failure to multiply at $18-20^{\circ} \mathrm{C}$. in unsterilized milk and also that the initial degree of contamination with Str. pyogenes had no influence upon their inability to multiply.

Epidemiologically it is difficult to account for scarlet fever outbreaks which have a considerable duration unless there is some nidus which continues to infect the milk.

In most recent outbreaks the cases consist of $\overrightarrow{\vec{p}}$ mixture of clinical scarlet fever with rash and sore throat and those without rash, so we should expece. causation to be similar to outbreaks of infective sore throat and the relationship of these outbreak $\$$ to infected cows is proved to the hilt.

In many of the more recent scarlet fever outbreaks. it has been possible to prove the association of the outbreak with a cow with an udder infected with $\underset{\&}{ }$ streptococcus of the same type as the human case. $ᄋ$

The 1936 Doncaster (Watson, 1937) outbrea黑 was a mixture of 135 sore throat cases with rash (scarlet fèver) and 229 similar cases without rash ${ }_{i \omega}^{\omega}$ and it was spread over 11 days. The source of infection was a cow with an indurated teat excreting the same streptococcus, Type 2, as was recovered from the patients. The 1939 Elgin (Douglas et al $\vec{D}$ 1942) outbreak with 214 cases, some with, some without rash, was due to a Type 3 strain recovere both from patients and the infected cow. The earlier Chelmsford (Camps and Wood, 1936\% outbreak of 1935 had the same clinical feature and was due to Type 2 . It lasted 11 days only an\& probably had the same causation but was no: proved, as unfortunately only. one cow was bacterio logically investigated.

Benedixen and Minett (1938) kept the Doncaste infected cow and a cow responsible for a similas outbreak at Morkov (Denmark) under observationThe Danish cow continued to excrete the Stro pyogenes strain from the affected quarter for at leas 13 months and the Doncaster cow for about six weeks.

In the U.S.A. this association with bovine infection is more widely recognized. Dublin et alo (1943) record that there were 57 outbreaks of scarlet fever and sore throat in New York (excluding New York City). The strain was typed in some outbreaks and three were Type 3, one Type 2, ant the rest other types. The majority were associate with an infected udder.

There is no evidence that the type of clinical case has any relationship to the streptococcus type although Evans (1946) from a study of 23 sucb strains suggests that this is so.

So far it has been a rare occurrence, but severe septic infection may be the essential feature as in the interesting little outbreak described by Golledgeo (1932) with four cases of whom two died. The $\bar{P}$ were infected from two cows suffering from mastitis? and the strain recovered from cows and patients was Str. pyogenes Type 1. 
When outbreaks result from direct infection of the milk, without cow intervention, they are usually explosive and limited in duration. The mixed scarlet fever and sore throat outbreak at Vejle in 1937 (Henningsen and Ernst, 1939) is a good example. About two-thirds of the cases were spread over four days, and the authors think that infection of the milk may have been confined to a single day. No evidence of cow infection was found, but the source was a milkmaid with purulent otitis media following unrecognized scarlet fever. Both from her and from many other cases Str. pyogenes Group A Type 3 was recovered.

\section{ENTERIC INFECTIONS}

Typhoid fever is usually water-borne, but sometimes the actual vehicle is milk contaminated with water containing typhoid bacilli used for washing utensils or for other purposes. Most milk-spread outbreaks are, however, due to direct infection of milk from a milk handler who is either an acute case or, more frequently, a chronic carrier.

Milk-spread typhoid outbreaks may be very extensive, such as the 1936 outbreak in Bournemouth and Poole (Shaw, 1937). This outbreak attacked at least 718 persons and caused about 70 deaths; it is also interesting since it was suggested that infection might have been transmitted through dung following systematic infection of a cow from drinking contaminated water. No evidence in support was adduced and direct experiments by Scott and Minett (1947) with a cow fed with virulent typhoid bacilli were entirely negative.

Improved methods for the isolation of B. typhosus and new methods which divide the bacillus in types have shown how wide may be the ramifications of milk-spread typhoid fever and also that comparatively few persons may be infected. Bradley (1943) supplies a particularly interesting illustration of 21 typhoid cases spread over two years (1941-42) and located in four different counties. This involved many milk distributors, and all the cases were traced to a typhoid carrier who infected the milk on a farm in Wiltshire $\mathbf{1 0 0}$ miles away. This carrier and all the cases were infected with the rather rare D4 type.

The important fact that these milk-spread outbreaks are by no means either always explosive in character or extensive is well illustrated by the little outbreak at Sedgley reported by Bekenn and Edwards (1944). Over a period of 10 months there were six apparently disconnected cases of typhoid fever, but all milk-spread and traced to one farm where an old woman of 78 years was a chronic typhoid carrier.

Paratyphoid fever is rarely water-spread but milk is a common vehicle. In a study of 40 recent outbreaks Savage (1942) records that eight were milk-spread, whereas 16 were from cream, fresh or ${ }^{\text {. }}$ mostly artificial, or cream cakes. The source of infection of the milk is a temporary or chronic paratyphoid bacillus carrier.

There is no doubt that not only have single cases and outbreaks of dysentery been more numerous in recent years but there has been a proportionate increase in those milk-spread. Their severity mainly depends upon the dysentery strain responsible. Those due to the Flexner type are often extensive and severe with a high mortality as in the Aberdeen (Kinloch, 1923) outbreak of 1919 with over 1,000 cases and 72 deaths. The most frequent causative strain in recent outbreaks has been the Sonne type, usually with a very low mortality. Outbreaks recorded over the past seven years, due to the Sonne type, are set out in Table VI. Frequently it was not possible to ascertain the exact source of infection.

Dysentery bacilli do not appear to grow easily or even to survive in raw milk, but Steuer (1941) records periods of survival of from one to 15 days at room temperature.

TABLE VI

Analysis of Outbreaks of Dysentery (Sonne Type) over Seven Years

\begin{tabular}{|c|c|c|c|c|}
\hline Year & Place & No. of Cases & Deaths & Authors of Report \\
\hline $\begin{array}{l}1942 \\
1942 \\
1942 \\
1943 \\
1944 \\
1945 \\
1945 \\
1947\end{array}$ & $\begin{array}{lll}\text { Cardiff } & . \cdot & \ldots \\
\text { Cumberland } & \ldots \\
\text { Penrith } & \ldots & \ldots \\
\text { Silloth } & \ldots & \ldots \\
\text { Dorset } & \text {. } & \text {. } \\
\text { Cheeping } & \text { Wycombe } \\
\text { N.E. Scotland } & \ldots \\
\text { Scotland } & \text {. . } & \ldots\end{array}$ & $\begin{array}{c}27 \\
43 \\
178+ \\
124 \\
57 \\
76 \\
250 \\
84+\end{array}$ & $\begin{array}{l}0 \\
0 \\
0 \\
0 \\
0 \\
0 \\
0 \\
0\end{array}$ & $\begin{array}{l}\text { Hobbs and Allison } \\
\text { Faulds } \\
\text { Faulds } \\
\text { Faulds } \\
\text { O'Keefe and Cooper } \\
\text { Muir and Vollum } \\
\text { Rae and Smith } \\
\text { Henderson, Michie, Rae, and Smith }\end{array}$ \\
\hline
\end{tabular}




\section{DiPHTHERIA}

Diphtheria outbreaks spread through milk are comparatively infrequent: nevertheless, as shown in the figures given, there have been a good many of them. The milk itself is directly infected from an actual case or a carrier of diphtheria bacilli, and usually such a person has been a milker. In some of the recent outbreaks, such as the East Yorkshire outbreak of 1941 described by Goldie and Maddock (1943), it has been possible to isolate $C$. diphtheriae from the infected milk. This outbreak is interesting for the small number of cases compared with those at risk. This has occurred in some other outbreaks and the factor of dilution is important.

An interesting feature in a few outbreaks has been the association of the human cases with sores shown to be infected with diphtheria bacilli on the teats of some of the cows. This was first noted by Dean and Todd in 1902 and later instances are recorded by Ashby (1906), Robertson (1911), Macdonald (1913), and McSweeney and Morgañ in 1928. They are surface infections and the bacilli do not invade the udder structure. Their possible occurrence is of epidemiological importance, since they may be responsible for prolonging infection and may explain continuance of cases without any explosive outbreak.

It is doubtful if diphtheria bacilli multiply readily in raw mixed milk. In a few experiments made by Goldie and Maddock (1943) the bacilli remained about the same number for four to six hours at room temperature but then gradually diminished.

\section{FoOd PoIsoning}

Milk may be the vehicle for two varieties of food poisoning, i.e. the staphylococcus toxin type and that due to Salmonella organisms.

Staphylococcus Food Poisoning.-Only a small minority of staphylococcus strains produce the special toxin (enterotoxin) which is responsible for symptoms of food poisoning. All are coagulasepositive, most are of aureus type, but only a proportion of strains with these properties produce enterotoxin and so cause food poisoning.

Many foods can act as a vehicle and milk is not a very common one, although it was responsible for the first recorded outbreak of this nature. A human carrier is the common source of infection but the possibility of staphylococci from the cow's udder being a source has been a good deal discussed. Staphylococci are fairly common in milk drawn direct from the cow's udder, healthy or diseased. Minett (1938) isolated 38 strains of Staph. aureus from the bovine udder, seven being from cows with acute mastitis, eight with chronic mastitis, and the rest from cows with normal udders. Enterotoxin? was reported, having been demonstrated with four $\$$ five, and seven strains respectively from these three? sources. This was based on the so-called " kitten, test," but results were negative or very indefinite when feeding experiments were conducted with human volunteers. Dolman (1941 and 1943), when has done so much valuable work on this variety of food poisoning, considers that endogenous infection of milk is an important source of infection. Out of 74 samples of raw milk examined he claims that $64 \overrightarrow{5}$ contained toxigenic staphylococci. The difficulty of accepting these findings is that they are based uporf the "kitten intraperitoneal test" which has been" severely criticized as unreliable. The only coms pletely satisfactory test is human feeding experimentș and these have not been used. The evidence suggests that only exceptional strains from miller produce enterotoxin and that this is not a commor source of infection.

An important fact in these outbreaks, with an food as a vehicle, is the significance of the time temperature factor after infection to allow sufficiento enterotoxin to be produced to set up food poisoninge

Salmonella Food Poisoning.-Outbreaks of thiø type are not infrequent, either from the direcof consumption of milk, or of its products. They map be extensive and are explosive in character. $O_{0}$ earlier outbreaks may be mentioned Newcastle-upon Tyne (1913), 523 cases, 0 deaths; Withnell an Chorley (1914), 317 cases, 2 deaths; Newcastle under-Lyme (1914), 468 cases, 2 deaths; Glasgow (1914), 370 cases, 0 deaths; Aberdeen (1925: 497 cases, 1 death. It is noticeable that in these milk-spread outbreaks the mortality is conspicuous 1 \% low.

For most of these outbreaks the source of infection. was a diseased cow. For instance, in the 1928 Aberdeen outbreak infection was traced back to cow with an indurated udder, which developed septicaemia from whom Sal. enteritidis was isolated from udder and flesh. The outbreak of 1947 from the same area was also traced to a cow which die from Sal. enteritidis dublin, and this strain was isolated from all organs. Probably most of these outbreaks were due to the Dublin sub-variety but the differentiation was unknown for the earlie outbreaks. The very. considerable extent to which Sal. enteritidis dublin is a cause of bovine infections has been only fully recognized in recent years and merits serious recognition. Boswell and Lovell as early' as 1931 described three outbreaks in calves due to Sal. dublin. Craig, Dävies, and Mass (1941) showed that this strain was responsible for number of cases in a herd in Cheshire, the cases 
cropping up over a number of years. They found no carrier cases. John (1946) gives particulars of four cases and found that all the cows that recovered became carriers and continued to excrete the bacillus for long periods. Bythell (1946) described outbreaks of 12 cases in all, one in Shropshire, and one in Staffordshire in 1945, when all the cases were fatal. Grunsell and Osborne (1948) found sporadic cases due to Sal. dublin on five farms in the Glastonbury (Somerset) area. The organism was isolated both from the faeces and the milk of infected animals. Field (1948) diagnosed bovine salmonellosis on 70 farms in west Wales during the two years 1946-47. Most of these resulted during the warmer (JuneOctober) months of the year. In all but four the strain responsible was Sal. dublin. In his cases most of the animals which recovered remained carriers, and were responsible for a number of subsequent infections, mostly to calves. He also showed that this strain can survive for long periods in faeces and also in water.

With such widespread herd infections, it is surprising that more human outbreaks from milk have not been recorded. One typical outbreak due to Sal. dublin occurred in a Wiltshire school (Conybeare and Thornton, 1938) with over 100 children affected with gastro-enteritis, the vehicle. being the school milk consumed raw. This strain was isolated from the patients, from the milk, and from the dung of one of the cows. The Knaresborough outbreak of 1944 (Sutherland and Berger) with at least 162 cases had exactly the same origin. In this outbreak the infective cow was transferred to the Weybridge laboratory for later investigation, and Rankin and Slavin (1947) found that the bacillus continued to be excreted in very large numbers (at one time 2,580 per g. in the excreta), but milk samples were negative.

\section{OTHER MilK-SPREAD Diseases}

Foot and mouth disease is an infection of cows which may be transmitted to man, but is decidedly rare. Whether infection is always direct or can be transmitted through milk is uncertain, but Dlugosz (1943) who describes two clinical cases without, however, any information as to method of infection, mentions that French scientists have experimentally proved infection through drinking milk. (The original reference cannot be traced.) Anthrax readily affects cows, but the animals die so quickly that spread through milk is a very unlikely contingency. In 1910 there was an extensive outbreak of anthrax in Chicago, involving 20 farms, and 87 cows died, but no persons were infected through milk.

The spread of epidemic poliomyelitis through infected milk has been advanced, but a study of the evidence shows that it is inconclusive and at present a verdict of " not proven" seems the correct attitude. Those interested will find evidence in favour of transmission in individual outbreaks in papers by Jubb (1915), Watts (1927), Aycock (1927), and Goldstein et al. (1946).

\section{Milk Products}

The only milk products which require consideration are cream, butter, and cheese.

Cream.-Cream being merely part of milk can convey all the diseases spread by milk if it is unpasteurized. Tubercle bacilli have frequently been found in raw cream. For example, Pullinger (1942) found tubercle bacilli in 16 out of 31 samples and $B r$. abortus in 11 out of the 31 .

Cream has been responsible for several outbreaks of paratyphoid fever (Savage, 1942) but less frequently than artificial cream. Typhoid fever outbreaks due to cream seem to be very infrequent although the typhoid bacillus survives for a good many days in cream, and Brock (1903) found survival for at least 10 days. It has been the vehicle in a good many outbreaks of staphylococcus food poisoning, but is rarely a vehicle in salmonella poisoning.

Butter.-Theoretically tubercle bacilli should not be infrequent in butter, but most investigations show a very low prevalence. For instance Edington (1934) out of 40 samples (14 from. Denmark, 25 from New Zealand, and one from Australia) found it in only one Danish sample. Pullinger (1935) failed to detect it in 39 samples, all except nine home produced. Br. abortus was also absent. Smith (1934) examined 51 samples of butter prepared on individual farms and five showed tubercle bacilli but no Br. abortus, but another series of 15 samples of English dairy butter, five of colonial, and eight from foreign sources were free from both organisms.

Pullinger and Kemp (1938) have shown that various salmonella strains (including $B$. paratyphosus $B$ ) can survive in both salted and unsalted butter for at least two months. Theoretically, therefore, they could be responsible for outbreaks of salmonella food poisoning, but the writer knows of no reported outbreaks either of this condition or of enteric outbreaks in Great Britain. On the other hand Studeny (1947) in Austria has reported three outbreaks of paratyphoid fever with butter as the vehicle. The first outbreak at Graz in 1940 of 143 cases was traced to butter supplied from a central factory and due to a paratyphoid carrier on the staff. Although a new factory was erected, a second outbreak was traced to a carrier on the staff of this 
factory also; 365 cases were spread by milk and butter. The third outbreak of 35 cases was from farmhouse butter derived from different hill farmers.

Cheese.-Cheese has been responsible for numerous outbreaks, and the literature is so extensive that space will only permit of a general summary. Direct experiments show that bovine tubercle bacilli can survive in cheese for many months, and Pullinger (1935) has demonstrated it on four out of 63 samples of cheese from various sources. No examples of human infection have been recorded, but such evidence is almost impossible to establish.

$B r$. abortus can rarely be found in cheese, and Smith (1934) failed to isolate it from 63 samples from various sources. On the other hand direct experiments have demonstrated its survival after inoculation for periods up to 60 days, but rarely beyond 50 days. Gilman, Dahlberg, and Marguardt (1946) specially studied survival and concluded that an ageing period of 60 days is adequate for safety.

The likelihood of infected cheese spreading undulant fever seems remote, but this does not seem true for infections by $\mathrm{Br}$. melitensis, for Celli (1944) has reported a small outbreak in Italy, and Veloppe and Jaubert (1925) an outbreak of 14 cases and two deaths from cheese eaten freshly made.

For well over 60 years cheese has been reported as responsible for outbreaks of food poisoning. Under the influence of the investigations by Vaughan (1903) these were ascribed to tyro-toxicon, a ptomaine-like body, but this conception has long been abandoned. Cheese continues to be a vehicle of food poisoning due either to salmonella strains or of enterotoxin type. Savage and White (1925) in their report of 100 outbreaks of food poisoning found that in eight the vehicle was cheese. Experimentally they showed survival of two salmonella strains in cheese up to 30 days but not beyond. Much more recently Tucker et al. (1946) held artificially inoculated cheese at $43-48^{\circ} \mathrm{C}$. and found survival of Salm. typhi murium up to 302 days. This organism was responsible for an outbreak of 384 cases and the vehicle was cheddar cheese sold soon after manufacture.

Many food poisoning outbreaks are recorded by Berberean (1946) in Syria and the Lebanon due to cheese, usually eaten as green cheese and prepared locally. Most are ascribed to Staphylococcus aureus. Erkmen (1941) refers to 21 outbreaks of food poisoning type (1937-39) in Turkey from cheese.

The writer is unaware of any recent outbreaks of typhoid fever or paratyphoid fever in Great Britain with cheese as the vehicle, but over recent years a considerable number has been reported in the U.S.A. and particularly in Canada. Some have $\stackrel{\mathbb{D}}{\circ}$ been extensive. For example, with six outbreaks in Canada the known cases have been 8, 21, 100, 29, 83 , and 40 , respectively, and of two in the U.S.A., 225 and 77 . Most of the cases have one feature in common, that the cheese has been eaten as "green cheese," i.e. before an adequate period of ripening $\overparen{\mathbb{}}$ has been allowed to elapse. One report will serve as an example. Menzies (1944) describes three क different cheese-borne outbreaks of typhoid fever in $\vec{\circ}$ Alberta, in 1936, 1938, and 1944. The cases in the $\overrightarrow{\vec{\omega}}$ 1944 outbreaks numbered 83 , with seven deaths all spread over a wide area with only cheese as a common vehicle. In all the cases fresh green $\stackrel{\circ}{?}$ Cheddar cheese made from raw milk was consumed. $\omega$ The source was traced to a typhoid carrier working $N$ in the production factory. These outbreaks raise of the problem of the survival of typhoid bacilli in cheese, and Campbell and Gibbard (1944) studied $\rightarrow$ this with three strains. Survival varied with the $\frac{7}{0}$ temperature of holding. At $40-42^{\circ} \mathrm{F}$. survival was $182-336$ days whereas at $58-60^{\circ} \mathrm{F}$. it was from $\bar{c}$ 35 to 196 days.

Canada, and at least seven states in the U.S.A., now require cheese to be made either from pasteurized milk or cream or to be held in storage from 60 to 120 days in the U.S.A. and for 90 days in Canada.

\section{REFERENCES}

Aycock, W. L. (1927). Amer. J. Hyg., 7, 791.

Bekenn, C. H. G., and Edwards, J. L. (1944). Mon. Bull. Min. Hlth, 3, 60.

Bendixen, H. C., and Minett, F. C. (1938). J. Hyg., Camb., 38, 374.

Berberean, D. A. (1946). J. Palestine Arab med. Ass., $1,30$.

Blacklock, J. W. S. (1947). Brit. med. J., 1, 707.

Bradley, W. H. (1943). Ibid., 1, 438.

Bruck, C. (1903). Dtsch. med. Wschr., 29, 460.

(1942). Bull. Emergency publ. Health Lab. Service, $ᄋ$ January, p. 12.

Bythell, D. W. P. (1946). Vet. Rec., 58, 425. Canad. J. publ. Hlth, 35, 158.

Camps, F. E., and Wood, J. L. M. (1936). Lancet, 2, N 756.

Cilli, V. (1944). Dairy Sci. Abstract, 6, 39.

Cruickshank, J. C., and Stevenson, G. A. (1942). Brit. ్ㅣ

med. J., 1, 522 .
Conybeare, E. T., and Thornton, L. H. D. (1938) Ministry of Health Public Health Report, No. $82 . \frac{\mathrm{Q}}{\overline{\mathrm{C}}}$
London.

Craig, J. F., Davies, G. O., and Massey, Kathleen M. (1941). Vet. J., 97, 145.

Cutbill, L. J., and Lynn, A. (1944). Brit. med. J., 1, 283.

Dalrymple-Champneys, W. (1948). Publ. Hlth, Lond., $\stackrel{\vec{D}}{\vec{D}}$ 61, 239.

Davis, D. J. (1914). J. infect. Dis., 15, 379.

Dlugosz, H. (1943). Brit. med. J., 1, 189. 
Dolman, C. E. (1941). Canad. J. publ. Hlth, 32, 183. (1943). Ibid., 34, 97, 205.

Douglas, R., Smith, J., Sutherland, I. N., and Watson, R. J. P. (1942). J. Hyg., Camb., 41, 543.

Duke, F. W. (1940). Lancet, 2, 517.

Dublin, T. D., Rogers, E. F. H., Perkins, J. E., and Graves, F. W. (1943). Amer. J. publ. Hlth, 33, 157.

Edington, J. W. (1934). Lancet, 2, 81.

Elkington, G. W., Wilson, G. S., Taylor, Joan, and Fulton, F. (1940). Brit: med. J., 1, 477.

Erkmen, R. (1941). Türk. Z. Hyg. exp. Biol. (German summary), $2,142$.

Evans, Alice C. (1946). J. infect. Dis., 78, 18.

Field, H. I. (1948). Vet. J., 104, 323.

Francis, J. (1947). “ Bovine Tuberculosis." London. Staples Press Ltd.

Gillman, H. L., Dahlberg, A. C., and Marquardt, J. C. (1946). J. Dairy Sci., 29, 71.

Goldie, W., and Maddock, E. C. G. (1943). Lancēt, 1,285 .

Goldstein, D. M., Hammon, W. M., and Viets, H. R. (1946). J. Amer. med. Ass., 131, 569.

Golledge, S. V. (1932). Vet. Rec., 44, 1499.

Griffith, A. S., and Griffith, F. (1911). Final Report of the Royal Commission on Tuberculosis, Appendix III. London.

- , and Munro, W. T. (1944). J. Hyg., Camb., 43, 229.

Grunsell, C. S., and Osborne, A. D. (1948). Vet. Rec., 60,85 .

Henningsen, E. J., and Ernst, J. (1939). J. Hyg., Camb., $39,51$.

Isaac, M. L., and Nussbaum, M. (1940). Amer. J. publ. Hlth, 30, Suppt. 1.

John, F. V. (1946). Vet. Rec., 58, 211.

Jones, E. R. (1943). J. Path. Bact., 55, 357.

Jones, F. S. (1928). J. exp. Med., 47, 965.

Jordan, C. F., Borts, I. H., Harris, D. M., and Jennings, J. R. (1943). Amer. J. publ. Hlth, 33, 773.

Jubb, G. (1915). Lancet, $1,67$.

Kinloch, J. P. (1923). J. Hyg., Camb., 21, 451.

Knudsen, Margrethe (1947). Ugeskr. Laeg., 109, 93.

Lange, B. (1932). Brit. med. J., 2, 503.

Lethem, W. A. (1946). Mon. Bull. Min. Hlth, 5, 80.

McSweeney, C. J., and Morgan, W. P. (1928). Lancet, 2, 1201 .

Menton, J. (1940). Med. Offr, 63, 33.

Menzies, D. B. (1944). Canad. J. publ. Hlth, 35, 431.

Minett, F. C. (1938). J. Hyg., Camb., 38, 623.

Munro, W. T. (1939). Edinb. med. J., 46, 165.

The People's League of Health (1932). Special Committee Report on a Survey of Tuberculosis of Bovine Origin in Great Britain. London.

Price, R. M. (1938). Canad. J. publ. Hith, 29, 251.
Priestley, F. W. (1934). J. comp. Path. Therap., 47, 181. Pullinger, E. J. (1934). Lancet, 1, 967. (1935). Ibid., 1, 1342. , and Kemp, A. E. (1937). J. Hyg., Camb., 37, 527.

(1938). J. Hyg., Camb., 38, 587.

Rankin, J. D., and Slavin, G. (1947). Vet. Rec., 59, 122.

(1934). Economic Advisory Council, Report of Committee on Cattle Diseases. Cmd. 4591. London.

Ritchie, J. N. (1948). J. R. sanit. Inst., 68, 503. , and Stamp, J. T. (1948). Tubercle, Lond., 29, 34,61 .

Ruys, A. Charlotte (1939). Ibid., 20, 556.

Savage, W. G. (1911). Proc. R. Soc. Med., 4 (Epidem. Section), 73.

(1929). "The Prevention of Human Tuberculosis of Bovine Origin." Macmillan \& Co., London. (1933). Brit. med. J., 2, 905.

(1942). J. Hyg., Camb., 42, 393.

, and White, P. B. (1925). Spec. Rep. Ser. med. Res. Coun., Lond., No. 92.

Scott, W. M., and Minett, F. C. (1947). J. Hyg., Camb., 45, 159.

Shaw, W. V. (1937). Ministry of Health Public Health Report, No. 81. London.

Smith, J. (1934): J. Hyg., Camb., 34, 242. (1934). Ibid., 34, 244.

Stamp, J. T. (1943). J. comp. Path. Therap., 53, 220.

Steuer, W. (1941). Arch. Hyg., Berl., 126, 233.

Studeny, O. (1947). Wien. med. Wschr., 97, 347.

Sutherland, P. L., and Berger, F. M. (1944). Brit. med.J., 1, 488.

Topley, W. W. C., and Wilson, G. S. (1946). Revised Wilson, G. S., and Miles, A. A. "Principles of . Bacteriology and Immunity:" Third Edition. Page 1698. London.

Torrance, H. L. (1936-37). Notts. County Council Report.

(1933). "Tuberculosis Infection in Milk." Report by the Department of Health for Scotland, Spec. Rep. Ser. med. Res. Coun., No. 189. H.M.S.O., London.

Tucker, C. B., Cameron, G. M., Henderson, M. P., and Beyer, M. R. (1946). J. Amer. med. Ass., 131, 1119.

(1948). Annotation Vet. Rec., 60, 302.

Vaughan, V. C., and Novy, F. G. (1902). Cellular Toxins, Philadelphia.

Veloppe, and Jaubert, (1935). Rev. Gen. de Med, Vet., 44, 513.

Watson, R. (1937). Brit. med. J., 1, 1189.

Watts, A. W. (1927). Ibid., 1, 114.

Wilsdon, A. J. (1937). Vet. J., 93, 403.

Wilson, G. S. (1942). "The Pasteurization of Milk." Edward Arnold \& Co., London. - (1932). Vet. Rec., 44, 1226, 1240. 